\title{
and Health (ICASSETH 2019) \\ Examining the Effectiveness of Reading Comprehension Practice via the Brain-Based Learning Model at SMPN Unggulan Indramayu
}

\author{
Dadun Kohar* \\ Indonesian Language Education Department, Faculty of Teachers Training and Education Science \\ University of Wiralodra \\ Indramayu, Indonesia \\ *dadunkohar@unwir.ac.id
}

\begin{abstract}
Text structure has a pivotal role in reading comprehension. It can be visualized in the form of different diagrams. By recognizing the text structure, the students are expected to be able to improve their reading comprehension on exposition text. Brain-based learning model is a learning model that corresponds to the way the brain naturally designed for learning. The present of the study is to examine (1) the effectiveness of the brain-based learning model, (2) the influence of brain-based learning model towards students' inferential comprehension, (3) the different influence of text structure towards exposition text reading comprehension. Grounded in quasi-experimental research with one group pretest and posttest design, this study provides a detail information of teaching reading via brain-based learning model. Sixty-four excellent students of grade VII SMPN Unggulan Sindang Indramayu grouped into the experimental group and the control group participated in this study voluntarily. Data collection include reading comprehension test and the data quantitatively analysed by statistical analysis. The results of this study showed that (1) brain-based learning model is effective, (2) brain-based learning model can improve students' inferential comprehension, $(3)$ there are different influences of text structure toward reading comprehension of exposition text.
\end{abstract}

Keywords: text structure, reading comprehension, inferential comprehension, brain-based learning

\section{INTRODUCTION}

One of the goals of learning Indonesian in schools is that students are expected to be able to speak and understand speech. Language skills that are receptive (understanding) will greatly assist students in understanding material in other fields of study.

At school students encounter a large number of textbooks that present information. These books usually contain exposition readings that are quite long and contain concepts that are quite difficult to understand. The purpose of reading these books in school is to achieve one of the most important learning goals, namely learning.

The previous of research indicated that the low the ability of students reading Indonesian language. The low reading ability of the Indonesian people is directly proportional to the low reading culture. The study "Most Littered National in the World", conducted by Central Connecticut State University in March 2016, Indonesia was ranked 60 out of 61 countries about reading interest [1].

The survey results above were strengthened by UNESCO statistical data as reported in 2012. The data stated that the reading interest index in Indonesia had only reached 0.001 . This means that for every 1,000 residents only 1 person has an interest in reading. This condition is certainly very alarming [2].

Empirically, Indonesian students' reading abilities internationally are still weak. The results of tests conducted by the Progress in International Reading Literacy Study (PIRLS) in 2011 to measure the results of reading literary texts and information texts on all items could not be answered perfectly by 4 th grade elementary school students [3].

The results of these studies indicate that there is something that needs to be improved and develop in teaching reading. In order to find an effective learning model, many educational praxes have translated the results of brain research into an educational praxis.

The use of brain research results in the world of education must be done [4]. Not only because education requires a brain, but also because education has the aim of optimizing the use of the brain. The optimal brain is a brain with all its potentials being well optimized [4].

The idea of uniting the right and left hemispheres of the brain in learning was also put forward by Given [4]. This learning system that unites the left and right hemispheres of the brain is called the natural learning system of the brain.

Actually, there were no studies that apply brain-based learning models in learning to read comprehension. Research conducted by Djiwatampu of SMPK students in Jakarta did not compare the learning model in teaching exposition reading structure diagrams, but looked at the level of effectiveness of exposition reading structure diagrams in reading comprehension [5]. Djiwatampu report that the group that received training on the exposition reading structure diagram and used it as a tool to understand a reading, showed a higher 
level of reading comprehension compared to the group that received training to make a reading frame [5].

Regarding the problems, the present of this study would like to investigate (1) the effectiveness of brain-based learning models, (2) the effect of using brain-based learning models on inferential comprehension abilities, and (3) differences in the effect of reading structures on reading comprehension.

\section{THEORETICAL FRAMEWORK}

Humans learn about many things in their lives. The results of learning manifest in daily behaviour. Psychologists usually associate learning with processes that bring about change in behaviour, but actual learning is not the only cause of this change [6].

From cognitive psychology perspective of information processing approaches. The information processing approach covers three areas of cognitive study, namely the study of (1) the phases or steps in the information processing series, (2) the processes or mental operations involved in each phase, and (3) the control and monitoring of processes the process [7].

The three cognitive studies are used as the basis of this research to explain the information processing model in reading. The study of the phases in the information processing series helps to explain the stages in learning, namely the acquisition, processing, storage, repossession of information and actions taken, for example answering questions. According to this theory learning begins from the activity of entering information into memory (encoding).

Allan Paivio states that memory is stored in long-term memory in one or two ways: as a verbal code or image / image code $[8,9]$. This theory predicts that the information presented visually and verbally is better remembered than the information presented in only one way.

Gestalt theory and research argued that materials that are well organized will be easier to learn and remember. Katona Miller argues that learning can be streamlined by classifying and grouping small pieces of information into large, organized pieces [6].

From the theory of reading taken the theory of the process of reading comprehension, reading comprehension measurement, and reading comprehension techniques. The process of reading comprehension is achieved through the formation / search of microstructure and macrostructure [5].

Measurement of reading comprehension is based on the theory put forward by Farr, Barret, Anderson, and Smith. Based on the theories of these experts, reading comprehension measured in this study is literal understanding and inferential understanding. This present study focused on three literal subinterpretations are taken, namely understanding of facts, understanding of relationships, and understanding of terminology and three inferential sub-interpretations, namely understanding of finding main ideas, making conclusions, and conducting elaborations.

There are many reading comprehension methods or techniques proposed by reading experts, such as reading frame techniques, SQ3R, SQ4R, PQ3R, PQRST, and reading structure diagram techniques, namely list structure, topic networks, matrices, hierarchies, series of events, and beeping trees. Reading comprehension technique used in research is the reading structure diagram technique.

From the learning model theory, theories are drawn about the components of the learning model, the kinds of teaching models processing information, and MPBO. The theory about the components of the learning model uses Joyce \& Weil's theory which states that a teaching model has four components, namely 1) orientation to the model, 2) the model of teaching, 3) application, and 4) instructional and nurturing effect [10].

The brain-based learning model (MPBO) is a learning model that belongs to the information-processing family group. The teaching model processes information based on cognitive knowledge theory. The theory studies how humans obtain information and knowledge, how they remember it, and how they relate one idea or concept to another idea or concept.

MPBO is a learning system that involves five main learning systems, namely emotional, social, cognitive, physical, and reflective learning systems.

Learning activities in MPBO consist of (1) pre-exposure, (2) preparation, (3) initiation and acquisition, (4) elaboration, (5) incubation and memory entry, (6) verification and checking of beliefs, and (7) celebrations and integrations [11]

\section{RESEARCH METHODOLOGY}

The Research Method that used is an experimental method because the data that will be collected is only available if the treatment has been carried out. Referring from the determination of sample, this research is quasi-experimental type because random procedures can't be carried out completely. In this research, the measurement was carried out twice, namely before and after treatment. On the basis of all that, the chosen research design is One-Group Pretest-Posttest Design [12] or Pre-test and Post-test Group Design [13]. The independent variable is the brain-based learning model (MPBO) while the dependent variable is reading comprehension both literal and inferential understanding.

Data were collected by test technique. The validity of the data is obtained by tests of normality and homogeneity. To test the normality used Chi Square ( ${ }^{2}$ ) data normality testing technique.

To test the homogeneity of t-test homogeneity testing techniques are used. Preliminary test data and MPBO class final test are not homogeneous, because tcount $(84,649)$ is greater than ttable $(2,042)$ at a significance level of $5 \%$ with $\mathrm{dk}$ 30 .

Data collected by reading comprehension tests which are processed using statistics. To test hypotheses related to the effectiveness of the learning model the t-test formula is used as follows [14].

$$
t=\frac{\bar{Y}_{1}-\bar{Y}_{2}}{\sqrt{\mathrm{Sy}_{1}{ }^{2}+\mathrm{Sy}_{2}{ }^{2}-2 \mathrm{r}_{12} \mathrm{Sy}_{1} \mathrm{Sy}_{2}}}
$$




\section{FINDINGS AND DISCUSSION}

TABLE I. SignificANCE Test ResUlts SignificANCE DifFERENCE INITIAL TEST AND MPBO Class FinAL TEST

\begin{tabular}{|c|c|c|c|c|}
\hline Pair variable & Dk & $\mathbf{T}_{\text {count }}$ & $\mathbf{t}_{\text {table }}$ & Interpretation \\
\hline $\begin{array}{l}\text { Pretest - posttest } \\
\text { reading } \\
\text { comprehension }\end{array}$ & 31 & 5,926 & 1,699 & Significant \\
\hline $\begin{array}{l}\text { Pretest }- \text { posttest } \\
\text { reading } \\
\text { comprehension } \\
\text { structure list }\end{array}$ & 31 & 3,192 & 1,699 & Significant \\
\hline $\begin{array}{lr}\text { Prestest }- & \text { posttest } \\
\text { understanding } & \text { of } \\
\text { structured } & \text { topic } \\
\text { network readings } & \end{array}$ & 31 & 3,07 & 1,699 & Significant \\
\hline $\begin{array}{l}\text { Pretest }- \text { posttest } \\
\text { reading } \\
\text { comprehension } \\
\text { matrix structure }\end{array}$ & 31 & 3,683 & 1,699 & Significant \\
\hline $\begin{array}{l}\text { Pretest }- \text { posttest } \\
\text { reading } \\
\text { comprehension of } \\
\text { hierarchical structure }\end{array}$ & 31 & 4,835 & 1,699 & Significant \\
\hline $\begin{array}{l}\text { Pretest }- \text { posttest } \\
\text { reading } \\
\text { comprehension of } \\
\text { series event structured }\end{array}$ & 31 & 3,981 & 1,699 & Significant \\
\hline $\begin{array}{l}\text { Pretest }- \text { posttest } \\
\text { reading } \\
\text { comprehension of tree } \\
\text { branch structures }\end{array}$ & 31 & 5,293 & 1,699 & Significant \\
\hline
\end{tabular}

The data above shows that the difference two mean scores between pretest and posttest of reading comprehension of the MPBO class was significant, because tcount (5.926) was greater than ttable (1.699). This means that MPBO was effective in learning to read comprehension.

In addition, MPBO is also proven to be able to improve students' reading comprehension ability from low to high.

In the reading structure of the list, topic network, and the matrix of students' reading comprehension ability was high, while the reading in the structure of hierarchy, series of events, and tree branches is quite sufficient. This difference is caused by the degree of difficulty of each reading structure.

This study also revealed that the ability of inferential understanding was not the same. For reading that has a list structure and topic network, it is categorized as high, while for reading that has a matrix structure, hierarchy, series of events, and tree branches, it is categorized as sufficient.

When compared to the pre-learning situation, in fact the ability of inferential understanding of MPBO class students for all types of reading structures has increased. In the reading structure of the list and topic network the ability of inferential understanding of students increased from low to high while in the reading that had a matrix structure, hierarchy, series of events, and trees with branches of inferential understanding students increased from low to sufficient.

Increased inferential comprehension ability is evidence that MPBO in learning to read comprehension can improve students' inferential comprehension abilities.
The data showed that the list structure reading is the easiest reading for students, while the tree structure reading is twig is the most difficult reading for students. The succession of exposition reading comprehension sequences is structured reading lists, matrices, topic networks, series of events, hierarchies, and relay trees.

\section{CONCLUSION}

The brain-based learning model (MPBO) was effective in reading comprehension at grade VII of the Sindang Indramayu Secondary school. T test calculation indicated that the tcount data $(5,926)$ was greater than the t table $(1,699)$. This means that the difference between the average initial test and the average final test was significant or significant.

Besides, MPBO was able to improve the ability to understand students' exposition reading. Before learning the ability to understand students 'exposition reading was low whereas after learning the ability to understand the students' exposition reading was in the high category. This study was also reported that MPBO had an effect on students' inferential comprehension skills although the effect was not the same for each type of reading structure.

In addition, the findings indicated that there was a significant influence of reading structure on reading comprehension. List structured reading is the easiest reading for students to understand, while tree-structured reading is the most difficult reading for students. Also, this study revealed that the fact sub-understanding was the sub-understanding that most students master while the lowest one is mastered subunderstanding. The succession of exposition reading comprehension sequences namely structured reading lists, matrices, topic networks, series of events, hierarchies, and relay trees.

\section{REFERENCES}

[1] Kompas.com, Monday, August 29, 2006

[2] www.paud-dikdas.go.id accessed April 12, 2016

[3] M. Suryaman, "Analisis belajar peserta didik dalam literasi membaca melalui studi internasional (PIRLS) 2011," LITERA Jurnal Bahasa, Sastra, dan Pengajarannya, vol. 14, no. 1, pp. 171-172, 2015.

[4] B.K. Given, Brain-based teaching: merancang kegiatan belajar-mengajar yang melibatkan otak emosional, sosial, kognitif, kinestetis, dan reflektif. Penerjemah: Lala Herawati Dharma. Bandung: Kaifa, 2007.

[5] M. Djiwatampu, Representasi mental dalam pemahaman bacaan: suatu studi eksperimental berdasarkan teori kognitif untuk melihat dampak pelatihan diagram struktur bacaan eksposisi terhadap pemahaman bacaan eksposisi. Disertasi, Jakarta: Universitas Indonesia, 1993, pp. 38.

[6] D.H. Schunk, Learning theoris an educational persepective; teori-teori pembelajaran: perspektif pendidikan. Edisi Keenam. Penerjemah: Eva Hamdiah \& Rahmat Fajar. Yogyakarta: Pustaka Pelajar, 2012.

[7] R.J. Sternberg, Psikologi kognitif. Edisi Keempat. Penerjemah Yudi Santoso. Yogyakarta: Pustaka Pelajar, 2008

[8] J.W. Santrock, Psikologi pendidikan. Edisi Kedua. Jakarta: Kencana, 2010.

[9] R.E. Slavin, Psikologi pendidikan: teori dan praktik. Edisi Kedelapan, Jilid 1. Penerjemah Marianto Samosir. Jakarta: Indeks, 2008

[10] B. Joyce, M. Weil, and E. Calhoun, Model of teaching model-model pengajara (Edisi Delapan). Penerjemah: Achmad Fawaiz dan Ateilla Mirza. Yogyakarta: Pustaka Pelajar, 2009. 
[11] E. Jensen, Brain-based learning: pembelajaran berbasis kemampuan otak; cara baru dalam pengajaran dan pelatihan. Edisi Revisi. Penerjemah: Narulita Yusron. Yogyakarta: Pustaka Pelajar, 2008.

[12] S. Sugiyono, Metode Penelitian Pendidikan: Pendekatan Kuantitatif, Kualitatif, dan R\&D. Bandung: Alfabeta, 2007.
[13] S. Arikunto, Prosedur penelitian suatu pendekatan praktek. (Edisi revisi IV). Rineka Cipta: Jakarta, 1998

[14] F. Furqon, Statistika Terapan untuk Penelitian. Edisi Revisi. Bandung: Alfabeta, 2004 